\title{
Integration of Seismic-Reflection and Well Data to Assess the Potential Impact of Stratigraphic and Structural Features on Sustainable Water Supply from the Floridan Aquifer System, Broward County, Florida
}

\section{Overview}

The U.S. Geological Survey (USGS) and Broward County water managers commenced a 3.5 -year cooperative study in July 2012 to refine the geologic and hydrogeologic framework of the Floridan aquifer system (FAS, fig. 1) in Broward County (Cunningham, 2013). A lack of advanced stratigraphic knowledge of the physical system and structural geologic anomalies (faults and fractures originating from tectonics and karst-collapse structures) within the FAS pose a risk to the sustainable management of the resource.

The principal objective of the study is to better define the regional stratigraphic and structural setting of the FAS in Broward County (fig. 1). The objective will be achieved through the acquisition, processing, and interpretation of new seismic-reflection data along several canals in Broward County. The interpretation includes integration of the new seismic-reflection data with existing seismic-reflection profiles along Hillsboro Canal in Broward County (Cunningham, 2013; Reese and Cunningham, 2014) and within northeast Miami-Dade County (fig. 2), as well as with data from nearby FAS wellbores. The scope of the study includes mapping the geologic, hydrogeologic, and seismicreflection framework of the FAS, and identifying stratigraphic and structural characteristics that could either facilitate or preclude the sustainable use of the FAS as an alternate water supply or a treated effluent repository. In addition, the investigation offers an opportunity to: (1) improve existing groundwater flow models, (2) enhance the understanding of the sensitivity of the groundwater system to well-field development and upconing of saline fluids, and (3) support site selection for future FAS projects, such as Class I wells that would inject treated effluent into the deep Boulder Zone (fig. 1).

\section{Data Acquisition and Processing}

Approximately 60 miles of high-frequency, marine seismic-reflection data were acquired by Walker Marine Geophysical Company in canals in eastern Broward County during 2013 (fig. 2). Excel Geophysical Services performed

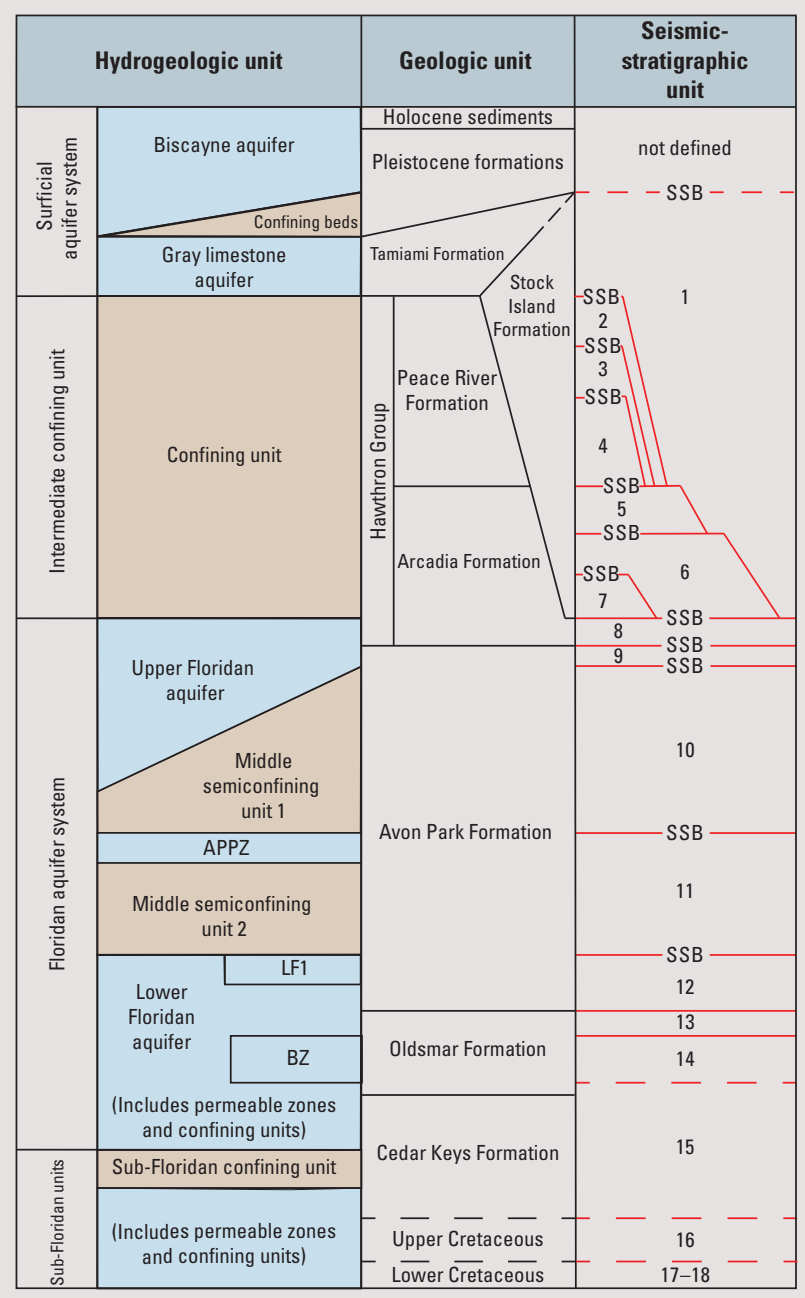

\section{EXPLANATION}

$$
\begin{aligned}
& \text { APPZ Avon Park permeable zone } \\
& \text { LF1 Uppermost major permeable } \\
& \text { zone of the Lower Floridan } \\
& \text { aquifer } \\
& \text { BZ Boulder Zone } \\
& \text { SSB Seismic-sequence boundary } \\
& \begin{array}{c}
-\quad \text { Geologic unit boundary- } \\
\text { dashed where } \\
\text { poorly defined }
\end{array}
\end{aligned}
$$

Figure 1. Generalized hydrogeologic units of eastern Broward County and correlation to seismic-stratigraphic units identified in seismic reflections and to geologic units. Modified from Reese and Cunningham (2014) and uses information from Roberts-Ashby and others (2013). 


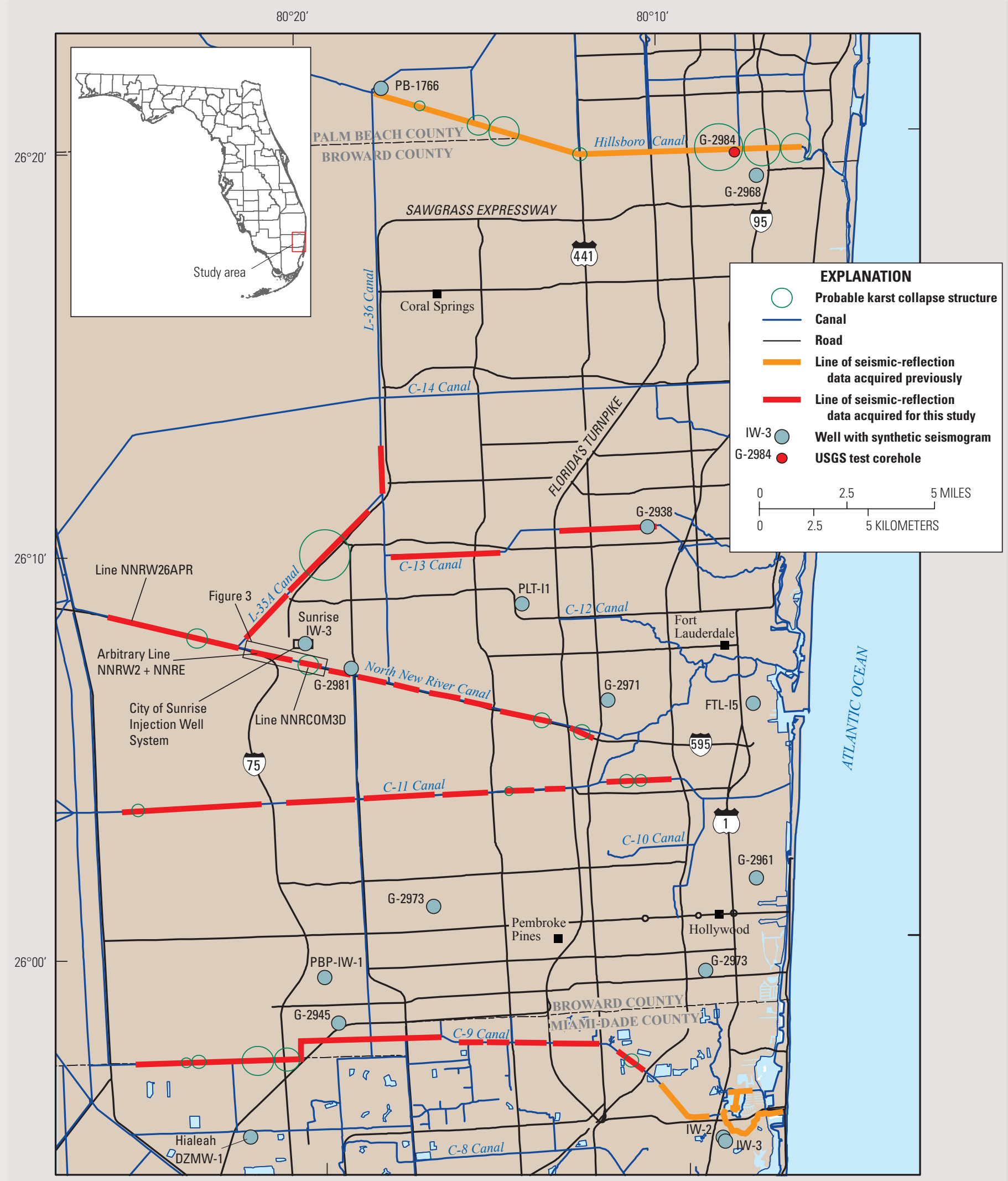

Figure 2. Locations of newly acquired (red lines) and existing (orange lines) seismic-reflection surveys used in the ongoing cooperative study between the U.S. Geological Survey and Broward County. Also shown are locations of probable karst-collapse structures interpretated on seismic-reflection profiles and locations of seismic-reflection profiles presented in figure 3. 
post-acquisition processing of the seismic-reflection data to produce 36 new seismic-reflection profiles (for example, fig. 3). Additional processing occurred at the Department of Earth and Planetary Sciences, University of California-Santa Cruz, as part of a USGS Cooperative Ecosystem Studies Unit agreement. Most of the seismic-reflection profiles are interpretable to a two-way travel time depth of about 0.75 second. Notably, one profile (NNRCOM3D, figs. 2 and 3) has an interpretable record to a two-way travel time depth of about 1.5 seconds. Eleven seismic-reflection profiles generated in one previous Broward County study (Reese and Cunningham, 2014) and one ongoing USGS study in Miami-Dade County augment the inventory of available seismic-reflection profiles. Specialized geophysical software was used to generate 15 synthetic seismograms using velocity data from borehole-compensated sonic logs as input (fig. 2).

The process of calibration of geologic properties in boreholes to seismic-reflection profiles uses synthetic seismograms. See Cunningham (2013, fig. 6) for an example of a synthetic seismogram produced using sonic-log data from a well in Broward County.

\section{Data Interpretation}

The principal focus of the study is to interpret the seismic-reflection data, including its integration with well data. Maps of geologic units and hydrogeologic units will be constructed by integrating the two-dimensional seismicreflection data and one-dimensional well data using seismicreflection interpretation software. Maps will be produced that show the depths of key horizons in two-way travel time as well as in feet.

Seismic-sequence stratigraphy — Preliminary stratigraphic analysis of the seismic-reflection data identified 18 provisional seismic-stratigraphic units, which probably extend from the uppermost rocks of the Lower Cretaceous and to the base of Pleistocene rocks and sediments (figs. 1 and 3). Many of the provisional seismic-stratigraphic units are seismic sequences sensu stricto (Mitchum and others, 1977), which provide information for developing a seismic-sequence framework in southeastern Florida. Fortunately, the Upper Floridan aquifer, Avon Park permeable zone, the uppermost major permeable zone of the Lower Floridan aquifer, and the Boulder Zone have predictable vertical positions that are included in the seismic-stratigraphic units 8 to 15 , and therefore seismicreflection stratigraphy provides a means for the detailed mapping of these hydrogeologic units (figs. 1 and 3). The use of seismic stratigraphy allows, for the first time in southeastern Florida, a level of resolution in mapping of hydrogeologic units never before accomplished using well data alone. Notably, the seismic stratigraphy can inform groundwater simulations designed to address the sustainability of the water resources of the FAS.
Structural features - Cunningham and Walker (2009), Cunningham and others (2012), Cunningham (2013), and Reese and Cunningham (2014) describe evidence of tectonic faults and karst-collapse structures on seismic-reflection profiles acquired in southeastern Florida. These faults and karst-collapse structures can span from the intermediate confining unit, the semiconfining and confining units included in the FAS, and sub-Floridan units (figs. 1 and 3).

Although preliminary observations have not identified any tectonic faults on the new seismic-reflection data acquired from Broward County, they have indicated numerous probable karst-collapse structures on nine seismicreflection profiles (figs. 2 and 3; Cunningham, 2013, fig. 3). Seismic-reflection line NNRCOM3D (figs. 2 and 3) displays one of the karst-collapse structures. This structure extends upward possibly from Lower Cretaceous carbonate rocks (Unit 17) to the approximate top of the Peace River Formation (locally Unit 3, fig. $3 A$ ), which is approximately coincident with the top of the intermediate confining unit throughout part of the study area (fig. 1). The location of the karst-collapse structure on seismic-reflection profile NNRCOM3D is along the North New River Canal about 3,000 feet to the south of the City of Sunrise Injection Well System (fig. 2). Detection of treated effluent in the uppermost major permeable zone of the Lower Floridan aquifer at this injection well system indicates that the source is upward migration of treated effluent from the Boulder Zone (fig. 3B; Montgomery Watson, 1996). Montgomery Watson (1996) indicates that the migration of treated effluent from the Boulder Zone to the uppermost permeable zone of the Lower Floridan aquifer (fig. $3 B$ ) was a result of the lack of confinement between the two permeable zones and "not of lack of mechanical integrity in the existing injection wells." Within the City of Sunrise Injection Well System, the absence of confinement between the uppermost major permeable zone of the Lower Floridan aquifer and the Boulder Zone is possibly enhanced by faults, fractures, and karst dissolution associated with the karst-collapse structure imaged on profile NNRCOM3D (figs. 2 and 3). A more dense occurrence of diffractions and offsets in seismic reflections exists in the Boulder Zone and the overlying part of the Lower Floridan aquifer upward to the top of the uppermost major permeable zone of the Lower Floridan aquifer (fig. 3B). Seismicreflection data therefore provide useful evidence for the presence of faults and fractures that can plausibly function as permeable pathways, where fluids can migrate upward.

\section{References Cited}

Applin, P.L., and Applin, E.R., 1965, The Comanche Series and associated rocks in the subsurface in central and south Florida: U.S. Geological Survey Professional Paper 447, 84 p. (http://pubs.er.usgs.gov/publication/pp447) 


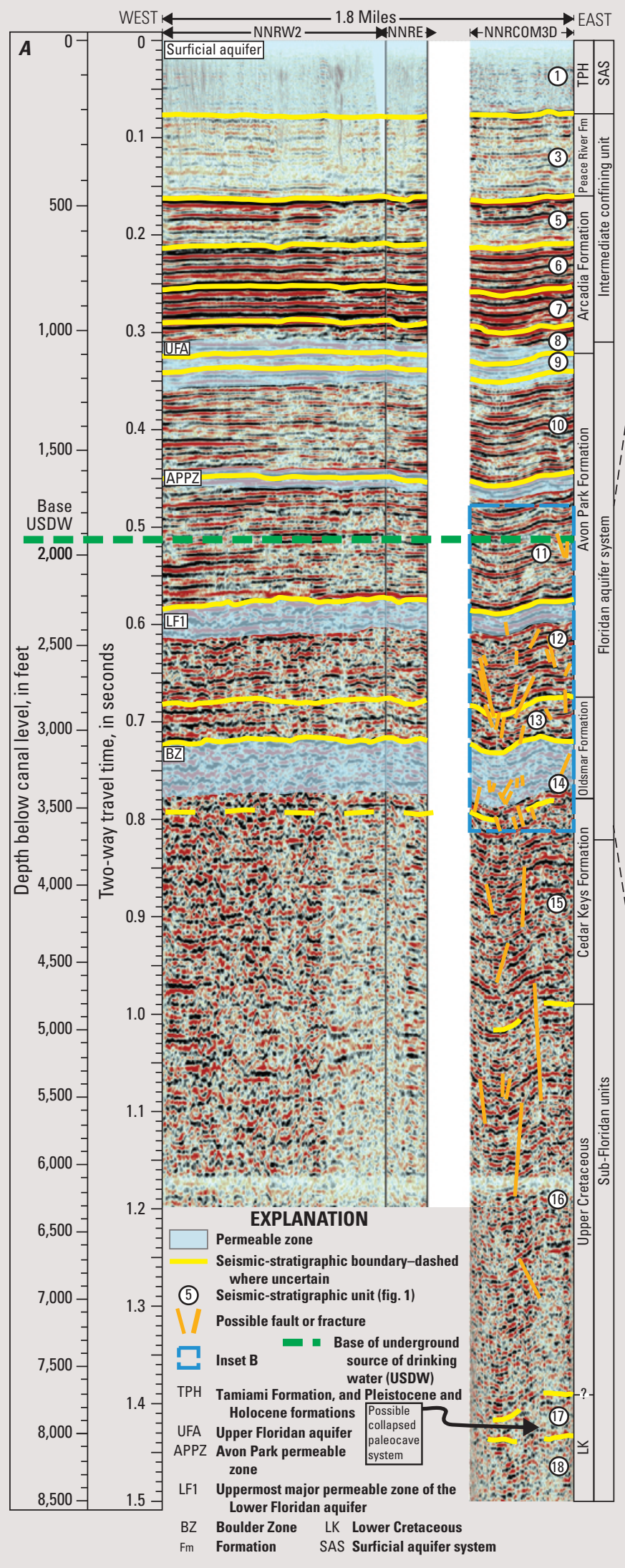

City of Sunrise Injection Well System projected southward about 3,000 feet onto seismic-reflection profile NNRCOM3D

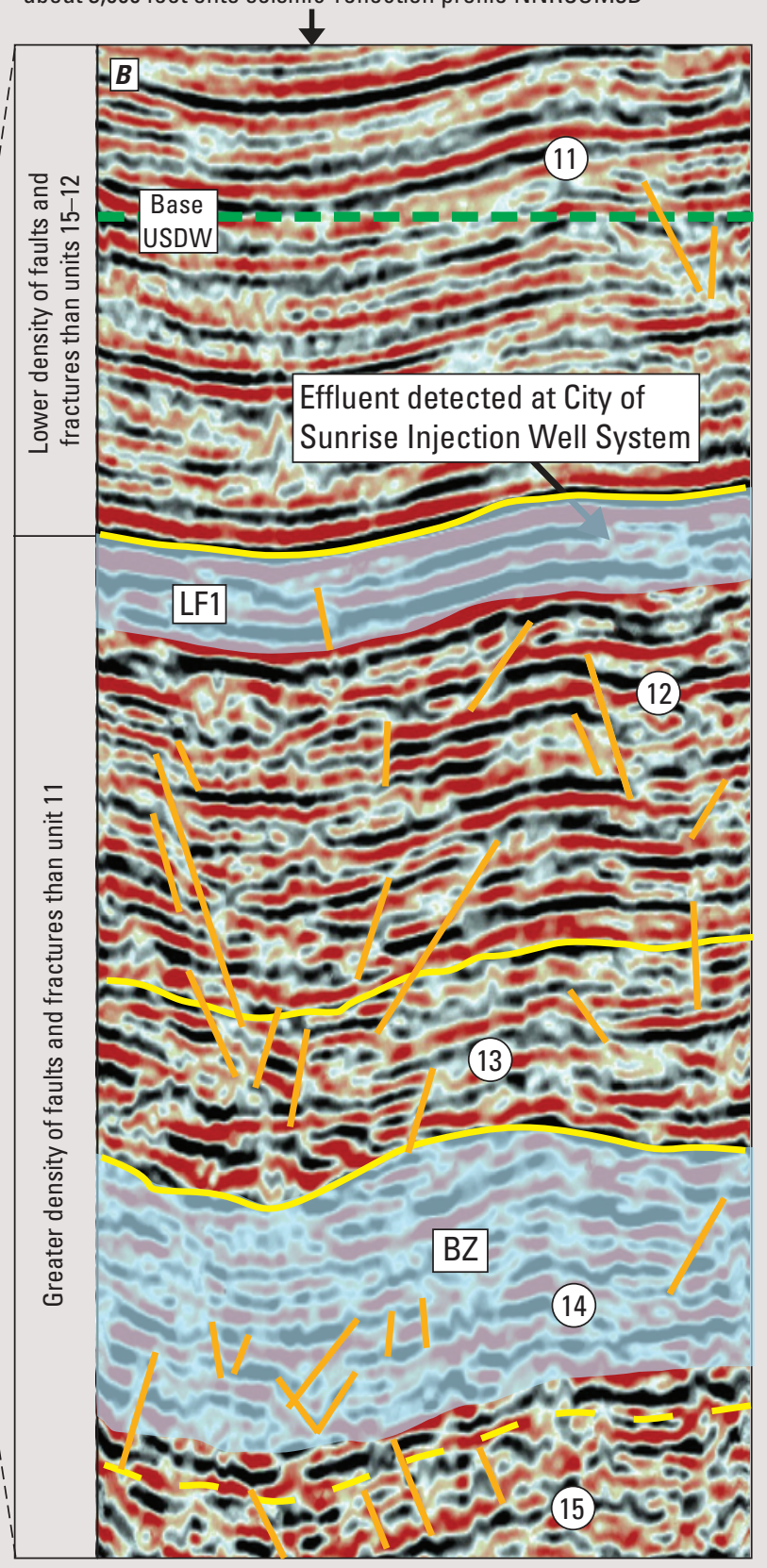

Figure 3. Seismic-reflection profiles NNRW2, NNRE, and NNRCOM3D (locations shown in fig. 2). (A) Sagging seismic reflections on profile NNRCOM3D provide evidence for a karst-collapse structure that extends upward from the Lower Cretaceous to the approximate top of the Peace River Formation. Top of Lower Cretaceous based on Applin and Applin (1965, Plate 9) and top of the Upper Cretaceous based on Roberts-Ashby and others $(2013$, fig. 8). (B) Inset from fig. 3A showing greater density of faults and fractures in seismic-stratigraphic units $15-12$, as compared to unit 11. Upward migration of treated effluent has been detected in the uppermost major permeable zone (LF1) of the Lower Floridan aquifer (Montgomery Watson, 1996) that plausibly migrated along faults and fractures upward from the Boulder Zone (BZ). Seismic-stratigraphic units 2 and 4 (fig. 1) are not present in seismic-reflection profiles NNRW2, NNRE, and NNRCOM3D. 
Cunningham, K.J., 2013, Integrating seismic-reflection and sequence-stratigraphic methods to characterize the hydrogeology of the Floridan aquifer system in southeast Florida: U.S. Geological Survey Open-File Report 2013-1181, 8 p. (http://pubs.usgs.gov/of/2013/1181)

Cunningham, K.J., and Walker, C., 2009, Seismic-sag structures in Tertiary carbonate rocks beneath southeastern Florida, USA - Evidence for hypogenic speleogenesis?, in Klimchouk, A.B., and Ford, D.C., eds., Hypogene speleogenesis and karst hydrogeology of artesian basins: Ukrainian Institute of Speleology and Karstology, Special Paper No. 1, Simferopol, Ukraine, p. 151-158. (http:// institute.speleoukraine.net/libpdf/Cunningham\%20Walker SEISMIC-SAG\%20STRUCTURAL\%20SYSTEMS\%20 IN\%20FLORIDA_HypoConf_2009.pdf)

Cunningham, K.J., Walker, C., and Westcott, R.L., 2012, Near-surface, marine seismic-reflection data define potential hydrogeologic confinement bypass in the carbonate Floridan aquifer system, southeastern Florida: Society of Economic Geophysicists Annual Meeting, Las Vegas, Nev., 6 p. (http://library.seg.org/doi/abs/10.1190/segam2012-0638.1)
Mitchum, R.M., Jr., Vail, P.R., and Thompson, S., III, 1977, Seismic stratigraphy and global changes of sea level, Part 6 Stratigraphic interpretation of seismic reflection patterns in depositional sequences, in Payton, C.E., ed., Seismic stratigraphy-Applications to hydrocarbon exploration: American Association of Petroleum Geologists Memoir 26, p. 117-133.

Montgomery Watson, 1996, City of Sunrise, Florida-Sunrise injection well system reaffirmation of the external mechanical integrity of IW-1 and IW-2: Lake Worth, Florida, Montgomery Watson, $55 \mathrm{p}$.

Reese, R.S., and Cunningham, K.J., 2014, Hydrogeologic framework and salinity distribution of the Floridan aquifer system of Broward County, Florida: U.S. Geological Survey Scientific Investigations Report 2014-5029, 60 p. (http:// dx.doi.org/10.3133/sir20145029)

Roberts-Ashby, T.L., Stewart, M.T., and Ashby, B.N., 2013, An evaluation of porosity and potential use for carbon dioxide storage in the Upper Cretaceous Lawson Formation and Paleocene Cedar Keys Formation of south-central and southern Florida: Environmental Geosciences, v. 20, p. 109-135.

\section{By Kevin J. Cunningham \\ U.S. Geological Survey \\ Carbonate Aquifer Characterization Laboratory \\ 7500 S.W. 36th Street \\ Davie, FL 33314}

http://sofia.usgs.gov/cacl/

For more information about this publication, contact:

Director

U.S. Geological Survey

Florida Water Science Center

4446 Pet Lane, Suite 108

Lutz, FL 33559

(813) 498-5000

or visit our Web site at:

http://fl.water.usgs.gov
For more information on the USGS - the Federal source for science about the Earth, its natural and living resources, natural hazards, and the environment, visit http://www.usgs.gov or call 1-888-ASK-USGS

Any use of trade, product, or firm names is for descriptive purposes only and does not imply endorsement by the U.S. Government.

ISSN 2331-1258 (online)

http://dx.doi.org/10.3133/ofr20141136

Prepared by the Raleigh Publishing Service Center 